\title{
Hume e as inferências causais
}

\section{Ulisses Cauê B.V.Fabian*, Silvio S.Chibeni.}

\section{Resumo}

O presente trabalho tem como objetivo discutir se seria correto atribuir a David Hume, tal como foi feito ao longo do século XX, a formulação do problema da indução a partir das suas reflexões sobre as inferências causais tendo como base a análise das obras de Hume, Bertrand Russell e da crítica feita por João Paulo Monteiro a essa atribuição.

\section{Palavras-chave:}

Hume, filosofia moderna, indução

\section{Introdução}

O presente trabalho tem três objetivos fundamentais. Primeiro, analisar a maneira pela qual David Hume expõe suas reflexões sobre o que ele denomina como inferências causais na Investigação sobre o entendimento humano. Segundo, expor a maneira pela qual as reflexões de Hume sobre esse tema foram interpretadas ao longo do século $X X$, tendo como referência a obra The history of western philosophy de Bertrand Russell. Terceiro, analisar a crítica feita por João Paulo Monteiro no artigo "Russell e as inferências humeanas" da atribuição feita à Hume da formulação do problema filosófico que ficou conhecido como problema da indução.

\section{Resultados e Discussão}

Ao tentar determinar os mecanismos através dos quais as nossas crenças sobre fatos que não constituem a nossa experiência sensível imediata ou as nossas inferências causais são geradas, Hume conclui que elas não poderiam ser geradas pelo entendimento ou por um processo de raciocínio, seja ele um raciocínio demonstrativo ou probabilístico. Em contraste, Hume considera que essas crenças são produzidas por um instinto que ele denomina como hábito ou costume. Graças a esse instinto, uma vez tendo observado repetidas vezes dois objetos ou eventos ocorrendo sucessivamente, ao observar uma nova ocorrência de um deles, a mente humana naturalmente esperaria a ocorrência do seu acompanhante usual.

Ao propor que as nossas crenças sobre fatos que não constituem a nossa experiência sensível imediata não são produzidas por qualquer processo de raciocínio, diversos filósofos ao longo do século $\mathrm{XX}$ acreditaram que Hume estava formulando o problema que ficou conhecido como problema da indução. Essa visão é particularmente divulgada por Bertrand Russell no livro The history of western philosophy. Russell afirma que o problema humeano da indução torna todas as nossas expectativas com relação ao futuro irracionais, pois ele estabelece que a experiência passada não é capaz de justificar as nossas crenças com relação ao futuro.

Essa atribuição feita a Hume da formulação do problema da indução foi intensamente criticada por João Paulo Monteiro no artigo "Russell e as inferências humeanas". É possível sintetizar as críticas feitas por Monteiro em três pontos fundamentais. Primeiro, Monteiro argumenta que o problema da indução, tal como ele foi concebido tradicionalmente, é um problema extremamente geral que se aplica a toda inferência indutiva. Contudo, a atenção de Hume se direcionava apenas a um tipo específico de inferência indutiva, a saber, as inferências causais. Segundo, Monteiro argumenta que, diferentemente do que muitos filósofos do século XX pensaram, tal como Russell, as inferências causais possuem, para Hume certa racionalidade ou razoabilidade. Terceiro, Monteiro argumenta que Russell estaria errado em considerar que o ceticismo indutivo humeano consiste na negação do que ele denomina como princípio de indução. Segundo Monteiro, Hume em nenhum momento se preocupou em afirmar ou negar esse princípio formulado por Russell.

\section{Conclusões}

A partir da análise das obras de Hume e das interpretações de Monteiro e Russell, acredito que a interpretação proposta por Monteiro é a mais coerente com o pensamento de Hume. Hume via seu próprio projeto filosófico como o desenvolvimento de uma ciência da natureza humana que teria como objetivo determinar os princípios de operação da mente a partir do método empírico. Portanto, seria extremamente curioso que Hume propusesse o uso do método empírico como fundamento de seu projeto filosófico e formula-se o problema da indução que torna, segundo Russell, nossas crenças sobre 0 futuro fundamentadas empiricamente completamente irracionais. Além disso, ao propor a utilização de um método de investigação das ciências naturais para a resolução de problemas filosóficos, muitos autores apontam semelhanças entre a posição proposta por Hume e a abordagem epistemológica conhecida como epistemologia naturalizada.

\section{Agradecimentos}

Este estudo foi fomentado pelo $\mathrm{CNPq}$ através do Programa Institucional de Bolsas de Iniciação Científica (PIBIC) da UNICAMP.

HUME, D. Investigação sobre o entendimento humano e sobre os princípios da moral. Tradução de José Oscar de Almeida Marques. São Paulo: Editora da UNESP, 2004.

MONTEIRO, J.P. "Russell e as inferências humeanas". In: Novos estudos humeanos. Lisboa: Imprensa Nacional-Casa da Moeda, 2003.

RUSSELL, B. The history of Western Philosophy. London: George Allen \& Unwin LTD, 1961. 